\title{
norden
}

\section{Sustainable Textile Production Tirupur, India}

Final report from a multi-stakeholder pilot implementation project in the Nordic countries and Tirupur, India

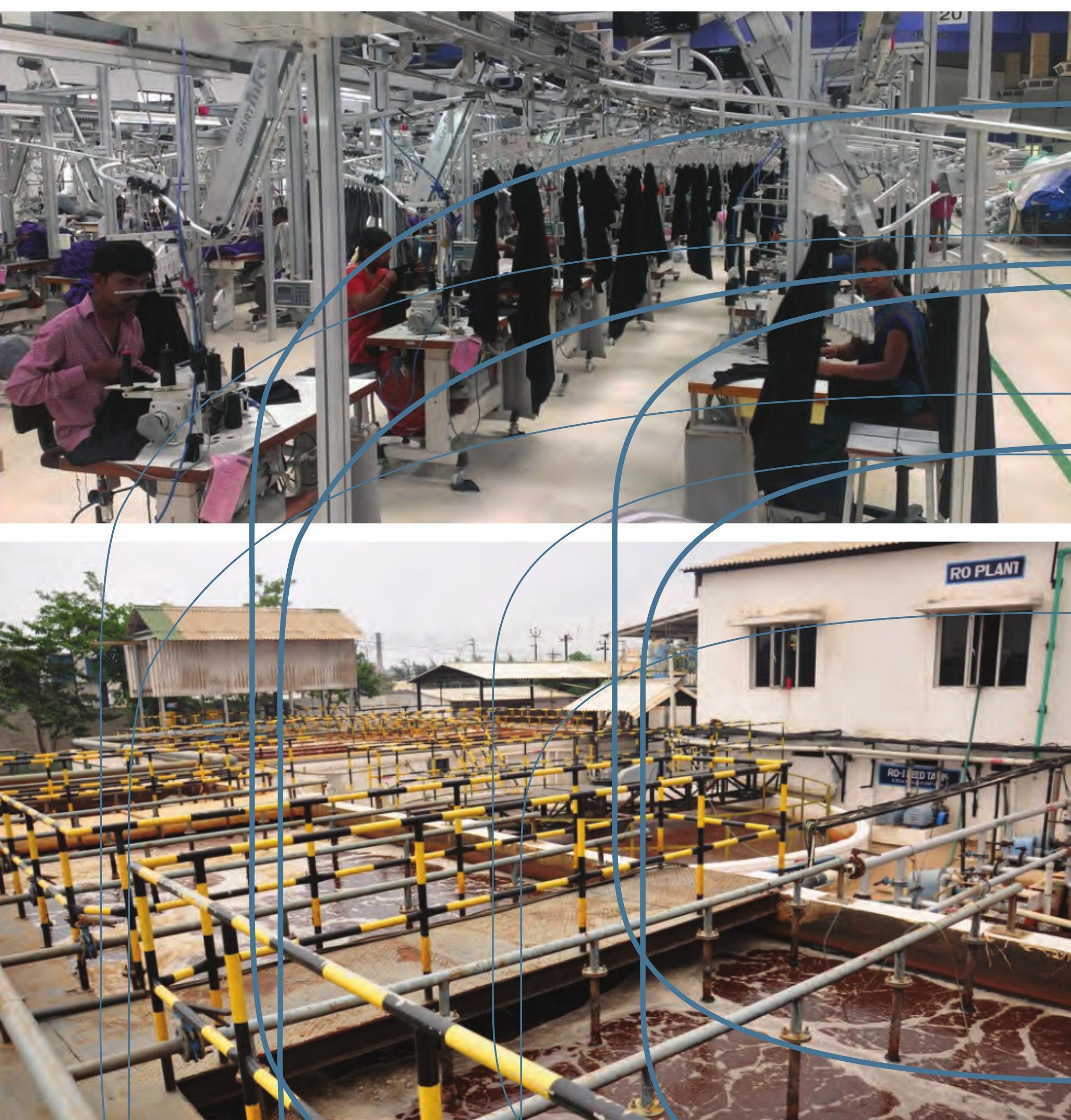



norden 



\section{Sustainable Textile Production Tirupur, India}

Final report from a multi-stakeholder pilot implementation project in the Nordic countries and Tirupur, India

Henning Høy Nygaard 
Sustainable Textile Production Tirupur, India

Final report from a multi-stakeholder pilot implementation project in the Nordic countries and Tirupur, India

Henning Høy Nygaard

ISBN 978-92-893-4058-8 (PRINT)

ISBN 978-92-893-4060-1 (PDF)

ISBN 978-92-893-4059-5 (EPUB)

http://dx.doi.org/10.6027/TN2015-527

TemaNord 2015:527

ISSN 0908-6692

(C) Nordic Council of Ministers 2015

Layout: Hanne Lebech

Cover photo: Claus Aabling

Print: Rosendahls-Schultz Grafisk

Printed in Denmark

This publication has been published with financial support by the Nordic Council of Ministers. However, the contents of this publication do not necessarily reflect the views, policies or recommendations of the Nordic Council of Ministers.

\section{www.norden.org/en/publications}

\section{Nordic co-operation}

Nordic co-operation is one of the world's most extensive forms of regional collaboration, involving Denmark, Finland, Iceland, Norway, Sweden, and the Faroe Islands, Greenland, and Åland.

Nordic co-operation has firm traditions in politics, the economy, and culture. It plays an important role in European and international collaboration, and aims at creating a strong Nordic community in a strong Europe.

Nordic co-operation seeks to safeguard Nordic and regional interests and principles in the global community. Common Nordic values help the region solidify its position as one of the world's most innovative and competitive.

\section{Nordic Council of Ministers}

Ved Stranden 18

DK-1061 Copenhagen K

Phone (+45) 33960200

www.norden.org 


\section{Content}

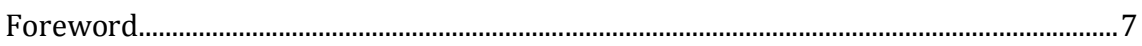

Executive summary ...................................................................................................................

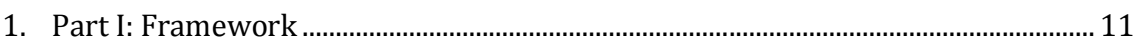

1.1 Project background.......................................................................................... 11

1.2 Project objectives ……………………........................................................... 14

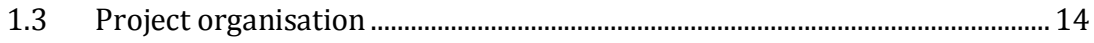

1.4 The Nordic Ecolabel.................................................................................................15

2. Part II: Project Activities ................................................................................................. 17

2.1 Project activities in Tirupur.............................................................................. 17

2.2 Project activities in Denmark, Finland and Norway.......................................... 18

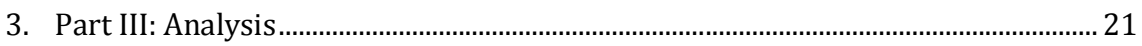

3.1 Barriers to Ecolabel implementation in Tirupur............................................2.

3.2 Potential in Tirupur .......................................................................................... 22

3.3 Barriers for Nordic companies ...........................................................................2

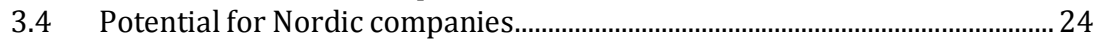

4. Part IV: Conclusions \& Recommendations ................................................................... 25

4.1 Future perspectives for Tirupur ......................................................................2 25

4.2 Attitude and interest from Tirupur suppliers....................................................26

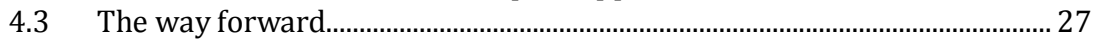

5. Sammenfatning (Danish Summary) ..........................................................................2 



\section{Foreword}

"The Potential for Green Textile sourcing from Tirupur - on the path to more sustainable global textile chains" and the project "Sustainable Textile Production Tirupur, India" are two pilot projects funded by the Nordic Council of Ministers' Working Group on Sustainable Consumption and Production. Both projects were designed and executed by the Danish Federation of Small and Medium Sized Enterprises and Danish Fashion and Textile, in co-operation with Ecolabel and textile organisations in Norway and Finland.

The Danish Federation of Small and Medium Sized Enterprises has extensive experience within CSR and environmental projects in the textile industry in Tirupur, as well as in other parts of India and countries in Africa and Latin America. Danish Fashion and Textile has thorough knowledge of environmental certification requirements and CSR issues within the industry.

The first pilot project was carried out from 2011 to 2012 with the main objective to analyse the current environmental situation in the textile industry of Tirupur, India and estimate the potential for Nordic textile companies to promote the EU Flower or the Nordic Swan Ecolabel as a comparative advantage in Tirupur industries. The investigation and final report was published in the Nordic Council of Ministers in 2013 and led to the follow-up project "Sustainable Textile Production Tirupur, India". This was a pilot implementation project investigating the need for capacity building in Tirupur, and working with Ecolabels among Nordic textile companies, utilising the advantages of working with a textile cluster one step ahead of other global competitors in the field of social and environmental compliance.

The project was managed by Mr. Henning Høy Nygaard from the Danish Federation of Small and Medium Sized Enterprises in collaboration with Pia Odgaard from Danish Fashion and Textile, in close cooperation with Ecolabel Denmark. The project team would like to thank our partners in Norway, Finland and India. We have received enormous support from textile organisations, companies and consultants from the Tirupur region and without them we would never have managed to complete this innovative project. Last but not least, we wish to express our gratitude to the companies that participated in the 
workshops and matchmaking events in Copenhagen and Tirupur. Their experience, knowledge and interest have been very valuable sources of information in identifying challenges and possibilities for promoting sustainable textile labels in the Nordic countries.

Sigurbiery Samundsdottir

Sigurbjorg Saemundsdóttir

Chair of the Nordic Council of Minister's

SCP working group, Ministry of Environment

Reykjavik, Island 


\section{Executive summary}

The pilot project "Sustainable Textile Production Tirupur, India" was kick started in Tirupur by the Danish Federation of SMEs in co-operation with Danish Fashion and Textile in the year 2013, with the findings from the project "Tracking Environmental impact in global production chains" in the year 2012.

Some dramatic changes have taken place in Tirupur since 2010 when the Madras High Court ordered the closure of practically all of the approximately 754 dyeing plants because of non-compliance with zero-liquid discharge (ZLD) norms. The ZLD norms refer to the effluent treatment process with $100 \%$ reuse of water resources. At first, the situation was desperate for the Tirupur textile industry, as the technology to handle the ZLD norms was not available in the dyeing units, but today a new beginning seems to be on its way. There is a growing interest among companies and public institutions in Tirupur to strengthen the green profile of the Tirupur cluster by defining some joint standards related to not only the ZLD norms, but also possibly to Ecolabel standards.

The objectives for this pilot implementation project were to promote sustainable production and knowledge of the Nordic/European Ecolabels in Tirupur, and to assist building local companies' capacity to comply with Ecolabels. In Denmark, Norway and Finland, the very first and initial dissemination of the Tirupur green cluster's competitive advantages took place in order to create a more social and environmental textile trade, in the long run.

The pilot project's milestone activities were successfully completed by conducting capacity building programs on EU/Nordic Swan Ecolabels in Tirupur, textile seminars in Norway, Finland and Denmark and a Buyer Seller Meet in Denmark. This report disseminates the lessons learned and the consolidated inputs from the stakeholder organisations and various opportunities to scale up the business between Nordic textile companies and the sustainable textile cluster of Tirupur.

The project clearly confirms that the Tirupur textile cluster has come a long way on the sustainable textile path and with some basic capacitation on Ecolabels, the certification process and technology requirements have made it possible for approximately 100 Tirupur companies to become certified within a very short time frame. Local interest is evident 
and more than 30 companies participated in all the information and training seminars regarding Nordic Ecolabels. In light of this project, the first five companies are in the process of becoming certified and a few have started trade with Nordic companies. The potential for an EU/Swan certified cluster could actually be realised in the near future. But the real obstacles relate to the lack of demand from Nordic textile companies and end consumers. At present, end consumers do not have the possibility to take an active vote on sustainable textiles, because only a few brands are to be found on the shelves. Only a few textile companies believe that their customers are willing to pay approx. 15\% extra for a certified product. But, Ecolabel certification is the only way forward in order to convince the Nordic buyers that people and the environment are protected according to international standards. For this reason, the project suggests that the Nordic companies pave the way for more sustainable brands to enter the marketplace and assist and share initial costs with the production companies. We recommend the Nordic Council of Ministers to support this process through branding, training and information campaigns about the advantages of Ecolabelling and collaboration with green textile clusters like Tirupur. 


\section{Part I: Framework}

\subsection{Project background}

\subsubsection{Introduction}

In the year 2012, the project "Tracking Environmental Impact in Global Production Chains" in the textile cluster of Tirupur, India, was financed by the Nordic Council of Ministers and executed by The Danish Federation of Small and Medium-Sized Enterprises (hereafter DFSME) together with Danish Fashion and Textile, Virke and TEKO - business associations of the textile and fashion industries in Denmark, Norway and Sweden respectively.

The initial phase comprised a research project and it concluded that due to the unique history and context of Tirupur, the textile cluster represented an optimal starting point for altering environmental standards in global textile production chains. Tirupur possessed the potential to become a best practice case that could be adopted by other production locations in India and internationally.

In October 2013, the Nordic Council of Ministers approved a followup project "Sustainable Production Tirupur, India", with more emphasis on implementation and capacity building of Ecolabels in India and in the Nordic countries. This is the final report for this project, covering activities from November 2013 to August 2014. The point of departure for "Sustainable Production Tirupur, India, was that the progressive environmental situation in Tirupur could be strengthened and create the foundation for a sustainable textile cluster, promoted by Ecolabels and Nordic textile companies.

\subsubsection{The situation in Tirupur}

In 1997, the Madras High Court ordered the first injunction to reduce the massive discharges of untreated wastewater into the local rivers from Tirupur's dyeing plants. The farming community was seriously affected by the wastewater discharged into the rivers, which they used to irrigate their crops. The injunction did not have much effect and was followed by more than 10 years of heavy lobbying from the farming community in 
order to stop this form of pollution. As a consequence, unique zero-liquiddischarge (ZLD) regulations were implemented by the local authorities, which was a hitherto unseen strict form of regulation. Most dyeing plants were not ready to implement the technology required. Hence, in 2011 the Madras High Court decided to close down the approximately 750 dyeing plants, which did not comply with the ZLD requirements.

These dyeing plants represented the majority of dyeing plants in Tirupur; hence the industry was hit hard. Consequences were, that the few dyeing plants which already possessed ZLD technology survived, some dyeing plants moved business to other regions, while others initiated implementation of expensive ZLD technology resulting in increased production costs and barriers to sustain existing markets and to grow new markets. Many companies were struggling to survive.

The analysis report from the 2012 project, "Tracking Environmental Impact in Global Production Chains", showed that this unique history on a global scale, provided a great potential to work with the textile companies in Tirupur, which were implementing - or had implemented - ZLD technology in order to promote their sustainable ZLD production methods. Since the companies were already on a path to greener production methods, the Nordic and European Ecolabels (the Swan and the Flower respectively), could be used as a framework for streamlining greener production for the companies of Tirupur, while at the same time the Ecolabels could be used as a competitive parameter when entering new green market segments. Thereby, the barrier to growth, which the ZLD regulations had initially been, could be turned into a competitive parameter which would place Tirupur on the world map as a green textile sourcing destination and best case example of green textile production (For more information on the green developments in Tirupur, please refer to the report "The Potential for Green Textile Sourcing from Tirupur - On the Path to More Sustainable Global Textile Chains", Nordic Council of Ministers 2013).

On the background of this, funding was provided by the Nordic Council of Ministers, for the pilot project described in this report - "Sustainable Textile Production in Tirupur, India". 


\section{Facts and figures about Tirupur (Figure 1)}

The textile cluster in Tirupur can be defined as:

- Most important area in India for cotton knit.

- Approx. 6000 textile companies, mainly smaller units.

- Limited number of vertically integrated (10\%).

- Many companies possess new technology, EMS and a number of certifications (25\% have environmental certifications and EMS).

- Most common certifications: ISO9001, ISO14001, GOTS, Oeko-Tex 100.

- Approx. 300.000 people employed in the sector.

- Exports: $35 \%$ to US, $55 \%$ to EU, $10 \%$ to ME, South America and Australia.

- Currently less than $3 \%$ of total European export goes to Nordic Countries.

\section{Timeline of events \& activities (Figure 2)}

\section{Year 2012 Year 2013}

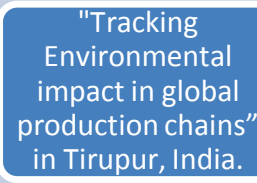

Awareness

Workshop on

"Market for

Sustainable Textile

in Denmark -

Potential and

Barriers"
Pilot Project on

"Sustainable Textile

Production Tirupur, India".

Consultative

Workshop To assess

and to Promote the

Sustainable Textile

Production in

Tirupur \& Promote

Business in Nordic

Countries
Year 2014

"Sustainable Textile

Production Tirupur, India". 


\subsection{Project objectives}

The project carried out activities in the Nordic countries as well as in Tirupur. Hence, there were different objectives for the different regions of intervention.

In the Nordic countries the objectives were:

- To strengthen knowledge of Tirupur's green cluster advantages.

- To promote collaboration between textile and Ecolabeling organisations.

The objectives in Tirupur were:

- To promote sustainable production and knowledge of the Nordic/European Ecolabels.

- To strengthen the local companies' capacity to comply with Ecolabels.

As the project was only a minor pilot project, no export oriented activities were originally planned. However, a long term goal was of course to strengthen business in "green" textiles between Nordic buyers and manufactures in Tirupur. For this reason, DFSME and DFT decided to invest additional time and money in order to be able to carry out a company matchmaking event in Denmark in June 2014.

\subsection{Project organisation}

The project was carried out in a consortium consisting of partners from Denmark, Norway and Finland:

\section{Denmark}

- Danish Federation of SMEs, DFSME (Lead partner).

- Danish Fashion and Textile, DFT.

- Ecolabelling Denmark.

\section{Norway}

- HSH - The Federation of Norwegian Commercial and Service Enterprises, VIRKE.

- Ecolabel Norway. 


\section{Finland}

- The Federation of Finnish Textile and Clothing Industries, Finatex.

- Ecolabel Finland.

Whereas DFSME contributed with extensive experience with Corporate Social Responsibility (CSR) and sustainable private sector development in developing countries, the Ecolabelling organisations contributed with in-depth knowledge and training capacity in Ecolabels. Finally, the national textile and fashion organisations contributed with sector specific knowledge and network with industry stakeholders and businesses.

\subsection{The Nordic Ecolabel}

The Nordic Ecolabel, the Swan, takes a lifecycle approach and encompasses environmental as well as social criteria. The lifecycle approach means that the criteria targets relevant social and environment impact in all phases of the life cycle of the product, from raw materials to the product is discharged as waste or recycled into new products. In addition to social and environmental criteria, quality criteria are also part of the Swan. The label is a product label - not a factory certification. This means that a factory cannot be certified, but the factory can apply for certification of their products. The factory then has to document that all criteria are complied with in all phases of the product's lifecycle. But, even for the fashion industry, it is possible to work with Ecolabels if the supplier uses the same approved sub-suppliers, approved colours and data sheets. This approval can be carried out up front or parallel to new customer sales. The Flower or the Swan is therefore more flexible and easier to work with than is anticipated by many companies.

The Swan is one of the most well known labels among Nordic consumers with around $90 \%$ of the Nordic population knowing the label. However, the label is not as widely used in the textile industry as it is on other products such as soap, body lotion, toothpaste, paper etc. 


\section{Recognition of Nordic and EU Ecolabel among consumers in Nordic countries}

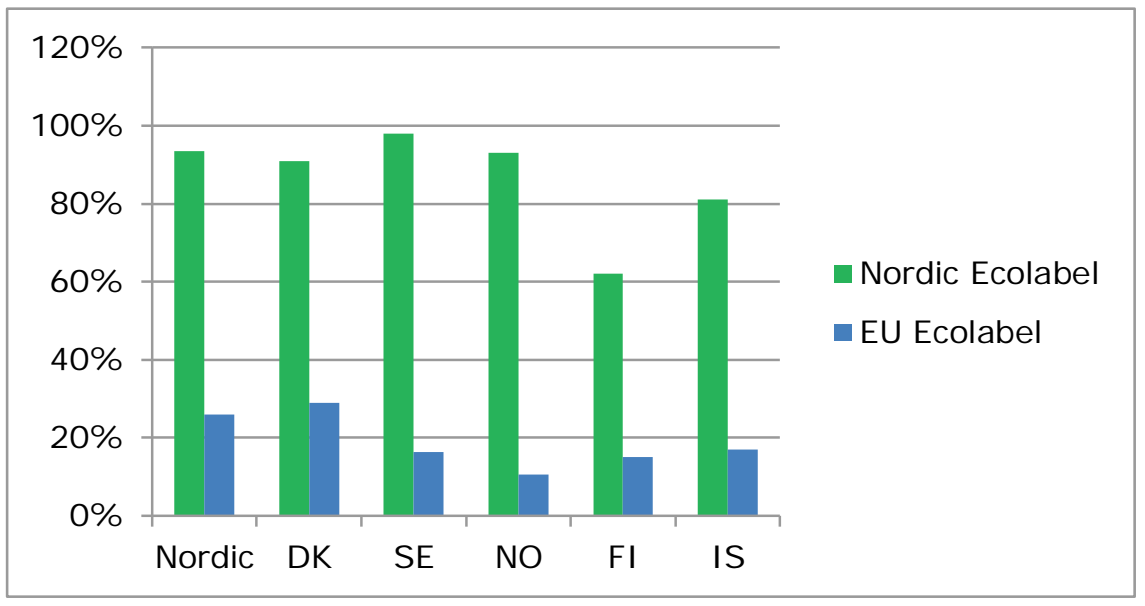

The idea of working with Ecolabels, focusing on the Swan, is to utilise standard criteria in the promotion of safe and environmental friendly products to Nordic consumers. The Swan also encompasses widely accepted CSR criteria. The objective of the project was also to test if producers in Tirupur could benefit from a certification, which would ensure a competitive advantage and fast returns on their CSR investments. 


\section{Part II: Project Activities}

\subsection{Project activities in Tirupur}

The project activities are divided between implementation and capacity building in Tirupur and promotion and information sharing in the Nordic countries. The following overview will start with the activities in India:

\section{Selection of a group of interested local companies and key organisations}

The first activity in Tirupur was to gather a group of relevant and interested local stakeholders. The project attracted strong local attention and the consisted of 37 companies and cluster/industry organisations.

\section{Start-up workshop in Tirupur and individual needs analysis for capacity building}

A consultative start-up workshop was held in December 2013 where 31 of the 37 stakeholders participated. The workshop was targeted at companies only and the 31 companies were subsequently subjected to an analysis of their current performance within sustainable business practices and with compliance to the Nordic Ecolabel criteria. This served as input to the project's capacity building activities.

\section{Capacity building of local companies and organisations - Swan and Flower labels and sustainable business models and market opportunities}

The culmination of the project in Tirupur was capacity building of local companies in the Nordic Ecolabel criteria and sustainable business models. The 31 companies from the start-up workshop were scrutinized down to 17 companies that were especially relevant to the intervention. The training was conducted by DFSME and Ecolabelling Denmark. The participating companies were trained in compliance with Nordic Ecolabel criteria and taken through a pro-forma certification process, so they were able to carry out all required activities in order to obtain Nordic Ecolabel certification for their various products. 


\section{Progress evaluation in participating companies}

A survey among the participating companies in Tirupur was conducted in August 2014 and in December 2014, in connection with a follow-up article about the project. One company from Tirupur has applied for Ecolabel status and 3-4 additional applications are in the pipeline. Knowledge about Ecolabels and potential customers in the Nordic countries has been successfully disseminated in the Tirupur textile cluster.

\subsection{Project activities in Denmark, Finland and Norway}

\section{Nordic start-up meeting}

The first activity in the Nordic countries was to kickstart the project and plan the details of implementation between the participating organisations. This was carried out in October 2013.

\section{Articles to promote progress and green initiatives in Tirupur}

A total of 6 articles about the project and the green market opportunities were published during the project along with information material and invitations to the different network meetings and seminars conducted throughout the project. This material was published in Denmark, Norway and Finland in newsletters, on websites and through the participating organisations' other information channels. In December 2014 a follow-up activity was initiated with interviews with Nordic and Indian companies in order to get their views on the results and the way forward. A final and concluding article was produced after the official finalisation of the project and will be available as an annex to this report.

\section{Network meetings for the Nordic textile industry}

During the project, a total of five network meetings were conducted in Denmark, Norway and Finland respectively. The seminars were open for Nordic companies and stakeholders alike and highlighted the possibility for, and benefits of, linking up with the project, especially for Nordic companies looking into new green sourcing opportunities. At the 5 seminars, a total of 51 Danish, Norwegian and Finish companies participated and were introduced to the project and were provided with the possibility to be linked up with the group of companies the project was working with in Tirupur. Various other stakeholders, from, for example, the national ethical trading initiatives, ministries of foreign affairs and environment also participated in the network meetings. 


\section{Delegation from Tirupur to the Nordic countries and dissemination of results}

Originally it was planned that a small delegation of textile organisation representatives from Tirupur would travel to the Nordic countries. However, due to great interest from the Tirupur companies, a delegation consisting of 7 companies from Tirupur and 2 cluster representatives was carried out in June 2014. The companies were willing to finance this activity with their own funds because they were able to see the benefits of being certified as green and sustainable textile producers. The 7 companies were participants from the training sessions in Tirupur and all capable of production in accordance with Nordic Ecolabel criteria. A half day seminar for Nordic companies and stakeholders was followed by a half day of speed dating between the 7 Tirupur companies and a total of 17 Danish and Norwegian companies (no companies from the Finish reference group participated). The seminar was a great success and a total of 51 participants from 31 companies and organisations attended.

The speed dating sessions were also very successful and each of the companies from Tirupur had the opportunity to meet between 6 and 8 Nordic companies.

The follow-up activity in December 2014 showed that one Nordic company had placed new orders with a supplier in Tirupur - but without Ecolabel certification. In addition, one supplier had submitted an application for the Swan to Ecolabel Denmark. Ecolabel Denmark explains that this may be the best application they have ever received from Asia. This indicates that capacity building has been successful. Ecolabel Denmark always carry out control visits before they can approve any final application. 


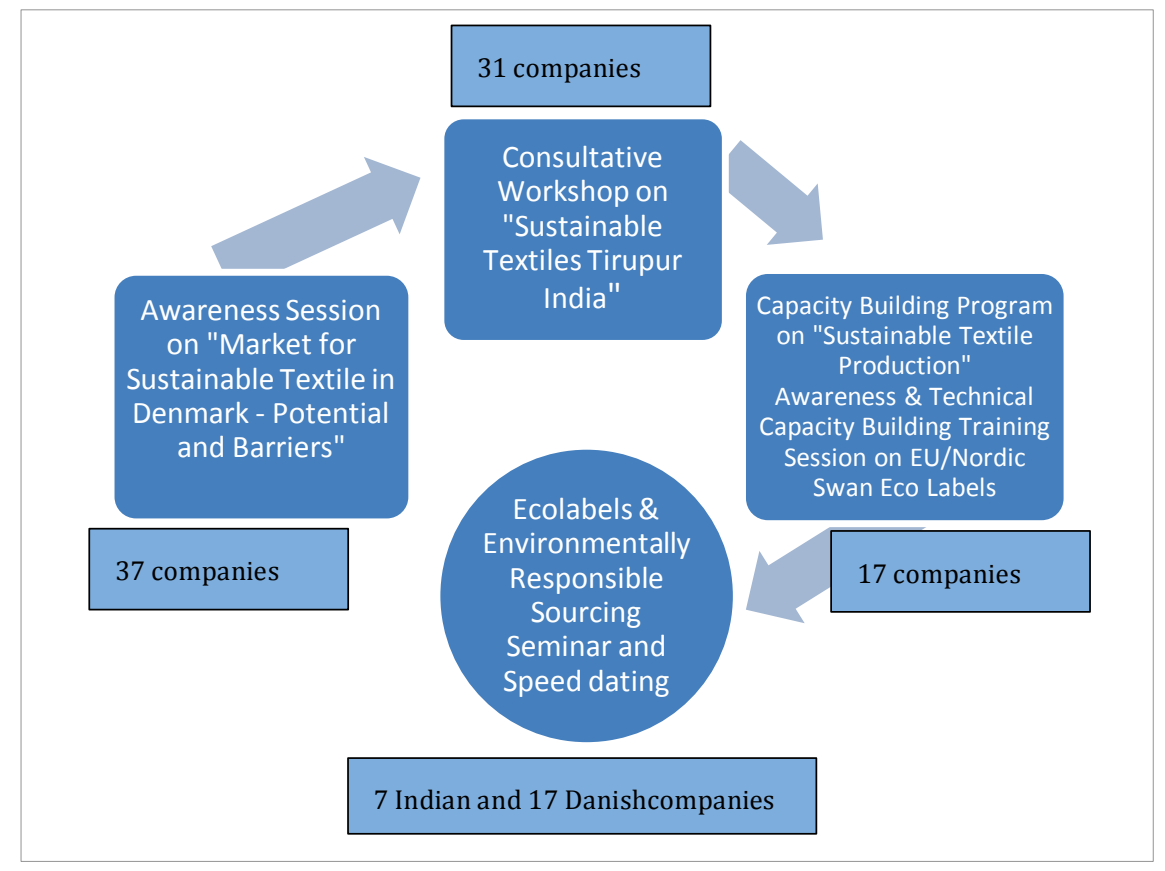




\section{Part III: Analysis}

\subsection{Barriers to Ecolabel implementation in Tirupur}

A clear picture arises from working with the textile companies in Tirupur. They are committed to learn and build capacity in order to be Ecolabel certified and benefit from the CSR investment they have already made in the production. BUT they are hesitant to invest any further in Ecolabel certification if their customers do not demand it and are willing to pay the extra cost. As mentioned earlier, the potential is there and one supplier has applied to get an Ecolabel licence and 3-4 are in the pipeline.

It is rather costly to get a licence to produce according to Ecolabel standards. The entrance and user fees are high but many companies are maybe even more are afraid of spending a lot of time on administration and paperwork. In addition, many environment friendly raw materials are more expensive, e.g. organic cotton and approved colours. An Indian company has estimated that an Ecolabel t-shirt will be 15\% more expensive to produce than one than without it. This extra cost cannot be managed by the small and medium sized producers in Tirupur alone. It will raise the price for Nordic buyers and they will only go for this solution if they already have the end customers for the final product.

If demands were bigger and costs lower, we would have at least 100 certified companies from Tirupur with the next 6 months.

In summary, we can outline the barriers as follows:

- Local infrastructure: Other labels such as Oeko-Tex, GOTS etc. have local consultants ready to assist companies with the implementation and certification. Swan has not. If the market demands Swan, consultants will come easily.

- Lack of demand. It is ok to implement a local intervention and build capacity from the bottom of the chain. But companies are not really committed until the demand is there.

- Lack of market knowledge and an innovative mindset: Local companies are not familiar with approaching green markets and do not know of the potentials of green marketing approaches. They are 
not thinking new thoughts and looking for new ways, but wait for the demand to come.

- Lack of supplier push. Suppliers are not willing to invest to obtain demands from new markets and they don't think in long-term perspectives. They primarily rely on following the demand.

- Mental barriers: Companies wanting to obtain Ecolabel certification for their products need a lot of transparency and an open dialogue with business partners in other parts of the chain. But, they are afraid that sub-suppliers of dyeing processes etc. will not disclose details about the products they use, as it may be seen as disclosure of sensitive information that can be used for calculating the subsupplier's costs etc.

- They have a reputation among Nordic brands as a T-shirt Mecca and not more than that. They are not known for their high quality. Things have changed in Tirupur, but they still need new skills with regard to quality and product types/required processes.

\subsection{Potential in Tirupur}

- Skills: The capacity building workshop showed that once companies get the assistance they need, they have the skills and are quick to find out how to go about the certification. It may be because they are used to working with other certifications. But, without assistance and capacity building they experience difficulties.

- It is relatively easy to get to a compliance level: The companies did not need much new technology or heavy investments to get compliance. As previous analysis has shown - and as the original argumentation for the pilot project stated - the Tirupur cluster is well acquainted with technologies that give a competitive edge when it comes to obtaining Ecolabel certification.

- Mindset (it is also a potential): There is a realisation in Tirupur that they have to come up with new ideas and business models in order to survive in the international market (they just don't know how to go about it).

- Familiarity: They are used to working with different compliance standards, Oeko-Tex, GOTS etc.

- First mover advantages in Tirupur when it comes to sustainable produced textiles. 
- Indian suppliers and consultants estimate that approximately 100 suppliers in Tirupur are ready to be certified with the Flower or the Swan if the price for certification were cheaper and the demand larger. It is estimated that 500 suppliers fulfil the requirements in SA8000 (social CSR standard) and that 1,000 suppliers fulfil the average Code of Conduct standards. With the implementation of ZLD technology, most challenges in the certification process will be managed because the colour and dyeing process are the most demanding in the overall environmental account.

\subsection{Barriers for Nordic companies}

- Ecolabels are seen as not being applicable in fast fashion because of the lengthy product certification process. Due to the time restraints connected to fast fashion, the somewhat lengthy certification process of the Swan and Flower prevents the labels from being attractive to the fast fashion segment. Typically, the labels appeal more to the workwear, children's wear, non-fashion and home textiles segments, where lead times are not as squeezed as within fast fashion. However, this common understanding among Nordic textile companies does not reflect the actual certification process according to Ecolabel Denmark. Today, it is possible to work with fast changing fashion if the value chain and a full colour palette have been certified (see potentials for Nordic companies).

- Finding qualified suppliers (quality, delivery and price).

- The Ecolabel standard is continuously revised. Some companies do not find it attractive anymore, because the organic cotton content criteria have decreased (less percentage of organic cotton is required now).

- Costs - time and money.

- Lack of demand from customers and consumers.

- Competition from other labels such as Oeko-Tex, GOTS etc., which are more well known than Swan in the textile industry. The problem is that the end consumers do not know enough about the content of the different certifications, e.g. Oeko-tex is often mistaken for an organic label. 


\subsection{Potential for Nordic companies}

- Nordic companies often think that the paperwork and administration of Ecolabels is more demanding than it is. The companies believe that the procedures for approval in production will delay delivery of the final goods. This is a misunderstanding. When a supplier has a cotton sub-supplier and a full colour palette approved they can in principal produce whatever they like from it. This will meet the demands from the fast changing fashion industry. They just need to use the same sub-suppliers and approved colours. This is the same in the case of printed products.

- Swan is a life cycle standard. One solution for all their CSR and quality certification needs.

- Nordic companies need additional information about the possibilities of working with the Swan certification process. It is easier and more flexible than they often think.

- Green trends are here to stay.

- If Tirupur is promoted more the cluster could function as a "one-stopshop" for swan labelled products, where they can find different suppliers to cater for different needs, all within Swan labelled textiles.

- Tirupur has numerous SMEs and trends toward green vertical collaboration between different links in the chain are on the rise. It will be easier for the typically relatively small Nordic buyers to find suppliers of a size willing and able to cater to their smaller order sizes.

- The Swan is close to being the most well known green label among Nordic consumers. This has huge potential. But consumers and brands have to start demanding and using it to a higher extent than in textiles. 


\section{Part IV: Conclusions \& Recommendations}

\subsection{Future perspectives for Tirupur}

From the Nordic companies' side, it is clear that there is indeed an interest for green sourcing. But it is also clear that the only certain market segments among Nordic buyers are interested in applying the Nordic and EU Ecolabel. When it comes to the prioritisation of "green suppliers", Nordic companies seem first to ask if a potential supplier can deliver the right quality at the right time, for the right price. Environmental and social compliance is very high on the agenda too, but it is not a first priority when looking for new suppliers, and it is not easy to "sell a potential supplier" to a Nordic company just by showing a strong environmental profile or Ecolabel compliance.

Never the less, interviews with Nordic textile companies also indicate that the companies are becoming more and more conscious about the commercial possibilities for Ecolabels and environmental friendly production. "We are sourcing from Tirupur today, because the area is interesting with a green cluster profile," replies Mr. Michael Jønsson, from Hummel A/S.

Several other Nordic companies express the same ideas and see Tirupur as a future, sustainable sourcing area. But a number of other factors need to be fulfilled before cooperation can start. Especially quality and workmanship need to be in place. In some cases, Tirupur needs to upgrade on these areas.

Despite of the major challenges with costs and demand for Ecolabels the project team agrees to the fact that Ecolabels are the only way forward to satisfy the customers' need for proof, control and high social and environmental standards. Several Danish textile companies have answered that they will consider buying products with the Flower or the Swan, if the certification process is straight forward and simple and without any delays for their production. The attention to Ecolabels has been raised, but misinformation related to administration and costs are also one of the reasons for not using the labels. 
All in all we can conclude that Ecolabels are the way forward for Tirupur despite the need for streamlining the application process and lower prices by sharing costs with buyers and end customers.

\subsection{Attitude and interest from Tirupur suppliers}

Feedback from producers in Tirupur shows that there is a very strong interest among Tirupur's textile manufacturers to promote the cluster as a green textile cluster. It is very clear that the industry feels "challenged by external factors" (Chairman of Tirupur Chapter of Confederation of Indian Industries - CII). The "external factors" mentioned particularly increase costs due to the investments in equipment needed to comply with zero liquid discharge requirements and the following difficulties in competing on the global market. It is also clear from the training conducted in May 2014 that there are still some gaps in terms of knowhow, management, quality and marketing skills in order to streamline the manufacturers so they can meet the Ecolabel criteria and approach the green Nordic highquality market segments, which many of the manufacturers have not targeted before. The companies see this project as an opportunity for new business in this green segment, but this project alone may not be able to sufficiently capacitate them in order to fulfil these hopes.

All together, this seems to indicate that there is a need for a more longterm capacity building of companies in Tirupur's textile industry, an increased marketing effort of Ecolabels and a need for a closer involvement of Nordic buyers in such an effort. This could hold the potential to ensure a sufficient engagement from the Nordic buyers, which could impinge positively on the commitment to improvements among the manufacturers in Tirupur, which would all in all increase the likelihood of a stronger green profile among Tirupur's manufacturers and actual strengthened Ecolabel usage and increased "green business" and as a result.

One of the main lessons learned relates to the prioritisations and decision making structures in the Indian companies. The Indian companies have shown that they are willing to adopt new sustainable strategies and focus on new markets where Ecolabels are in demand. And many of them have the technology and investments available in order to meet environmental demands and other criteria laid down by Nordic/EU Ecolabels. They are very flexible in this regard. On the other hand, they are not very patient when it comes to opening up new markets, and their marketing skills are not very advanced. This means that they are waiting for the market pull before they will adopt Ecolabels, instead of trying to 
create this market through a market push. Lack of proximity to the market, lack of market knowledge and lack of knowledge of Ecolabels (i.e. for companies which have not participated in the project's activities) are additional barriers for them to implement Ecolabels. This indicates that there is a need for more export promotion activities and activities which raise Ecolabel awareness and create links between Ecolabel interested buyers and the companies willing and able to supply them.

\subsection{The way forward}

Our conclusions, so far, indicate that there is a huge need for an increased marketing effort of Ecolabelled textiles directed towards the end consumer, which would drive demand and consequently create the market pull that the Indian companies require. This claim is strongly supported by the Nordic companies engaged in the project. Awareness of the Swan is very high in Nordic countries (around $90 \%$ are familiar with the Swan), but still it is not widely known as a textile label and is competing with labels such as GOTS and Oeko-Tex, which are better known as textile labels. A parallel can be drawn to the Fairtrade label, where it has been realised that marketing of the label cannot rely on the companies using the label alone. The organisation behind the label also has to drive the demand for the label, which Fairtrade, for example, is now doing successfully.

Ecolabel certification is the only way forward in order to convince the Nordic buyers that people and the environment are protected according to international standards. For this reason, the project suggests that the Nordic companies pave the way for more sustainable brands to enter the marketplace and to assist and share initial costs with the production companies.

We recommend Nordic Council of Ministers to support this process through branding, training and information campaigns about the advantages of Ecolabelling and the collaboration with green textile clusters like Tirupur.

The project partners are committed to continue working with these aspects and utilise the strong momentum and awareness, which the project has gained in Tirupur and the Nordic countries up till today. 
We suggest that a future NCM intervention for sustainable textiles should focus on:

- Marketing and branding of the Swan as a textile Ecolabel. The marketing campaign should focus on Nordic textile companies and end consumers in the Nordic countries.

- Information dissemination directed towards Nordic textile companies regarding the potential for working with Tirupur as a responsible green textile cluster.

- Support matchmaking activities between companies from Tirupur and the Nordic countries with focus on Ecolabelled products. 


\section{Sammenfatning (Danish Summary)}

Pilot projektet "Sustainable Textile Production Tirupur, India" blev igangsat af Håndværksrådet, i samarbejde med Dansk Mode \& Textil, i 2013, på baggrund af resultaterne fra projektet "Tracking Environmental impact in global production chains" fra 2012.

Tirupur har siden 2010 gennemgået en række dramatiske forandringer. Det skete efter at Madras High Court gav ordre til lukning af 754 tekstil-farverier, fordi de ikke levede op til normerne for "nul-udledning" (zero-liquid discharge - ZLD) til floder og grundvand. ZLD normen betyder en grundig spildevandsrensning med $100 \%$ recirkulation af vand. I starten var situationen desparat for tekstilindustrien, da investeringer og teknologi ikke var tilstede for at kunne leve op til kravene. I dag ser det ud til at udviklingen er vendt, og mange af farverierne er genåbnet og kravene til ZLD overholdes. Det har betydet en voksende interesse blandt virksomheder og organisationer for at styrke Tirupurs grønne profil ved at definere nogle fælles standarder. Ikke kun i forhold til ZLD regulativet, men også i forhold til brugen af miljømærker som EU Blomsten og det nordiske Svanemærke.

Formålet med dette projekt var at fremme bæredygtig produktion og viden om miljømærkerne Svanen og Blomsten i Tirupur samt facilitiere kapacitetsopbygning hos lokale virksomheder. I Danmark, Norge og Finland er der blevet afholdt workshops og seminarer for at promovere Tirupurs komparative fordele ved at producere efter høje sociale og miljømæssige standarder. Krav der ofte bliver stillet til sektoren af både myndigheder og forbrugere.

Projektets aktiviteter og milepæle er blevet gennemført efter planen og alle parter har investeret ekstra ressourcer i projektet for at nå de bedst mulige resultater. I Indien er der gennemført workshops og træning i hvordan man efterlever og ansøger om Blomsten og Svanen. I Danmark, Norge og Finland er der gennemført tekstilseminarer om Tirupur og miljømærkning. I Danmark blev der i juni 2014 desuden gennemført et trænings- og match-making event for 7 indiske og 17 danske og norske virksomheder. Denne rapport skal være med til at dele de erfaringer som 
organisationer og virksomheder har gjort sig i forsøget på at etablere en bæredygtig tekstil produktion båret af miljøcertificerede produkter.

Projektet konkluderer, at Tirupurs tekstil klynge er kommet rigtig langt med bæredygtig og miljøvenlig tekstil produktion. 100 Tirupur virksomheder har erklæret, at med kapacitetsopbygning og assistance til certificeringsprocessen vil de, inden for en kort tidshorisont, være klar til at blive certificeret efter Blomsten eller Svanen. Mere end 30 virksomheder har deltaget i projektets træningsseminarer vedrørende miljømærkning. De første fem virksomheder er allerede i gang med at blive certificeret og nogle få har startet direkte handel med nordiske virksomheder.

På trods af de positive erfaringer fra projektet, vurderes det, at der fortsat vil gå lang tid før vi ser en større gruppe certificerede tirupur virksomheder. Dette skyldes mangel på efterspørgsel fra nordiske virksomheder og forbrugere. Nordiske virksomheder henviser til manglende forbrugerinteresse og evne til at betale lidt mere for tøjet. Samtidig har forbrugerne svært ved at demostrere deres interesse, da de ikke har valgmulighederne i butikkerne. Kun få nordiske tekstilvirksomheder har tiltro til at deres kunder vil være i stand til at betale ca. $15 \%$ mere for miljømærket tøj. Projektet anerkender disse udfordringer, men vurderer samtidig, at certificeret, miljømærket tøj er den eneste mulighed for at sikre forbrugerne et produkt, de kan stole på.

Derfor anbefaler projektet, at nordiske virksomheder og myndigheder skal være med til at vise vejen ved at promovere miljømærkede produkter. Præcis på samme måde som man har gjort for økologi og farirtrade mærkede produkter. For at fremme en ny type bæredygtig beklædning kunne myndighederne reducere import told på miljømærkede tekstil produkter. Samtidig kunne nordiske tekstilvirksomheder og producenter i Tirupur gå foran ved at dele de øgede omkostninger. Projektet anbefaler, at Nordisk Ministerråd støtter denne process gennem oplysningskampagner, branding og træningsaktiviter, der fortæller om fordelene ved miljømærkning på tøj og muligheden for at samarbejde med en bæredygtig tekstil klynge, som Tirupur. 
Nordic Council of Ministers

Ved Stranden 18

DK-1061 Copenhagen K

www.norden.org

\section{Sustainable Textile Production Tirupur, India}

Global textile production chains are currently under pressure to become more sustainable. The Nordic Council of Ministers Working Group on Sustainable Consumption and Production has initiated a pilot project in order to understand how stakeholders in global textile production chains can support the pace of change, through the application of Eco-labels and environmental management systems in Tirupur, India where Zero Liquid Discharge norms for dye factories have been implemented, as well as improved labour practices and social and human rights. Nordic textile companies can benefit more from this development and encourage producers to continue on this track. This project conducted capacity building programs on ecolabelling, seminars in Norway, Finland and Denmark and a Buyer Seller Meet in Denmark. It's recommended that the NCM supports further needed efforts for sustainable textiles.

TemaNord 2015:527

ISBN 978-92-893-4058-8 (PRINT)

ISBN 978-92-893-4060-1 (PDF)

ISBN 978-92-893-4059-5 (EPUB)

ISSN 0908-6692 